\title{
REGIONAL DIFFERENTIATION OF POLAND IN TERMS OF THE DEGREE OF DIGITAL EXCLUSION OF HOUSEHOLDS IN 2017
}

\author{
Aneta Becker, $\mathrm{PhD}^{1}$; Jarosław Becker, $\mathrm{PhD}^{2}$ \\ ${ }^{1}$ Faculty of Economics, West Pomeranian University of Technology \\ ${ }^{2}$ Faculty of Technology, Jacob of Paradyz University in Gorzów Wielkopolski
}

\begin{abstract}
Nowadays, the digital economy plays a significant role in economic life. It is determined by the intensive development of modern ICT (Information and Communication Technology). Thus, the importance of the information society using techniques of information communication and processing that arose from the connection of other households is increasing. These households participate and form the basis for the process of creating social capital. Therefore, it seems interesting to examine the socio-economic space of Polish households due to the existence of disproportions in ICT development. The article presents the results of the classification of Polish voivodeships in terms of the degree of digital exclusion understood as lack of access or the ability to use ICT in households in 2017. The research used the ELECTRE TRI method, which is an example of a multicriteria decision support method used to classify decision variants based on a relationship of exceedance. The obtained results allowed for the identification of regions that are characterized by the highest degree of exclusion of digital households (the lowest use of ICT). This group includes the following provinces: Podlasie, Lublin and Lubusz. Into the analyses carried out additionally and deliberately introduced the region of Masovia Province without the capital city and separately the region of Warsaw (the capital city), which clearly different from other units. Thus, it served as a reference point in the study, which represents highly urbanized areas of voivodeships characterized by a low degree of digital exclusion.
\end{abstract}

Keywords: ICT, digital divide, households, ELECTRE TRI

JEL codes: $\mathrm{C} 38, \mathrm{O} 35$

\section{INTRODUCTION}

The importance of information in the modern world is enormous. It is used in all areas of socio-economic life. The Internet plays an important role in the process of acquiring, collecting and transferring information. Access to it and the skilful use of its resources result in the promotion of society to the group of highly developed countries. The inability to use in- formation and communication technologies can lead to digital exclusion, defined in literature as stratification for those who have access to computers and the Internet and those who do not have this access (van Dijk, 2010). The effect of these activities is unequal access to information and thus exclusion from the group of information societies.

In Poland, research on the information society is conducted within the framework of the Statistical

\footnotetext{
${ }^{1}$ Corresponding author: Janickiego 31, Szczecin, Poland, abecker@zut.edu.pl, +4891 4496861

${ }^{2}$ Corresponding author: Fryderyka Chopina 52, Gorzów Wielkopolski, Poland, jbecker@ajp.edu.pl, +4895 7279536
} 
Research Program of the Public Statistics. It forms the basis for the evaluation of the implementation of the assumptions of the 'Digital Poland Operational Program' for 2014-2020 (Ministry of Investment and Development, 2018). This strategy is aimed at: enabling wider access to fast Internet, cultural heritage and science, as well as increasing interest in communication with state administration and increasing the digital competence of residents. It is worth paying attention to Poland's involvement in digitalization. The latest update of OECD from October 2017 indicates that Poland in 2013-2015 recorded a decrease in total revenues from telecommunications services (OECD, 2018). The accumulated annual growth rate (Compound Annual Growth Rate - CAGR) was at the level of USD -8.45 million. While the total value of investments in telecommunications infrastructure in terms of CAGR amounted to USD -8.5 million. The ICT Development Index (IDI) ranking published in 2017, which is an index of the development of information and communication technologies published by the United Nations Telecommunications Union indicated that Poland advanced by one degree compared to 2016 and took the 49th (out of 176 assessed countries of the world) place with the index at 6.89 (International Telecommunication Union, 2017).

The aim of the article is to classify Polish voivodeships in terms of the level of digital exclusion understood as lack of access or the ability to use Information and Communication Technology (ICT) in households in 2017. In the classification tests, the multi-criteria decision support method ELECTRE TRI was used. The empirical material used in the research came from the resources of the Central Statistical Office (GUS, 2018) and contained information on the use of ICT in Polish households.

\section{THEORETICAL BACKGROUND}

Prof. Bernard Roy is considered to be the founder of the European school of decision-making (Dias and Mousseau, 2003). While the representatives of this school developed a new methodology for making decisions and constructed a number of multicriteria methods. Among them, the family of ELECTRE methods can be distinguished, which can be applied in the decision-making problems, e.g. selection, ordering and grouping (Merad et al., 2004). The extensive review of the applications of these methods and applications related to them was made by Govindan and Jepsen (2016). An interesting item that contains a collection of articles on multi-criteria decision analysis is the work of Figueira et al. (2016).

The ELECTRE method family is based on the $S$ superiority relation. It is a binary relation that says that variant $a$ exceeds variant $b(a S b)$ if, given the available information on the decision-maker's preferences, there are clear indications that variant $a$ is at least as good as variant $b$ and there are no compelling reasons for rejecting this statement (Roy, 1991; La Gauffre et al., 2007; Roy and Słowiński, 2008; Figueira et al., 2009). The ELECTRE TRI is a representative of the ELECTRE method family, which can be used for classification (grouping) issues (Doumpos and Zopounidis, 2002; La Gauffre et al., 2007). Among the latest literature, in which the authors indicate the use of ELECTRE TRI, the following articles deserve attention: Corrente et al. (2016), Sanchez-Lozano et al. (2016), Becker et al. (2017) and Lu et al. (2010).

The main idea of ELECTRE TRI are the socalled profile separating classes from each other. Each decision variant (object) can be described because of its values on the criteria (features). The criteria weights and thresholds are the input data: indistinguishability, preferences and veto. It is required to enter the number of classes and define their boundaries, i.e. separating profiles. The operation of the calculation procedure is based on the performance of a series of tests of compliance and non-compliance (La Gauffre et al., 2007; Roy and Słowiński, 2008). This method compares each decision variant with all class separating profiles. Then you get a series of hypotheses that say if the variant exceeds the thresholds or not. Four situations may emerge from the tests: the variant is preferred over the profile, the variant is worse than the profile, the variant is indistinguishable from the profile or the variant is incomparable with the profile (Doumpos and Zopounidis, 2002; Dias and Mousseau, 2003; Merad et al., 2004). In the ELECTRE TRI method, placement of objects in individual classes follows 
two complementary procedures: optimistic and pessimistic (Doumpos and Zopounidis, 2002; La Gauffre et al., 2007).

\section{USE OF ICT IN HOUSEHOLDS (EMPIRICAL MATERIAL)}

The empirical material containing information on the use of ICT in households in Poland, in 2017 came from the resources of the Central Statistical Office (GUS, 2018). The participation in a direct interview was voluntary. Participants were people aged 16-74. A two-stage sample selection scheme with stratification on the first stage was used to obtain results with smaller random errors. At first, the drawing of field research points was performed, and then of the apartments. The sample was taken using the Social Research Service. Completeness of the study was improved by using the reserve sample. The sample survey included a small part of the population and was generalized to the entire population as a result of multiplication by appropriately designated weights. In 2017, the response rate in the study of ICT use in households was $71 \%$.

In 2017, the percentage of households (among respondents) that had at least one computer at home was $81.8 \%$. Internet access was declared by $81.9 \%$ of households. The Internet users used the network primarily to: read or download the press $(60.3 \%)$, communication via e-mail (59.8\%), search for information about goods or services $(58.4 \%)$ and use the social networking sites (48\%). Communication with offices was less popular. Only $21 \%$ of households returned completed official forms, while $20.6 \%$ obtained information from public offices and public institutions, and $20.2 \%$ downloaded official forms. Only $11.6 \%$ of the survey participants marked the use of the network in order to look for work and send applications via the Internet. Factors conducive to greater interest on the Internet were having children and living in a large city (over 100,000 inhabitants) with a high degree of urbanization. As the reason for the lack of Internet access, $18 \%$ of respondents mentioned: no need to use the network $(68 \%)$ and lack of skills (54\%), equipment costs $(27 \%)$ and access costs (19\%).

\section{DISCUSSION OF MULTI-CRITERIA GROUPING RESULTS}

The study took into account the layout according to NUTS 2013 voivodeships (Eurostat, 2018). In this way, information in ICT in households from sixteen voivodeships was obtained. The unit, which was divided into additional regions, was the Masovia Province. In this way, the list of facilities has been extended to eighteen (, that is, the capital region of Warsaw and the region of the Masovia Province without Warsaw (the capital).

The research used a ten-element set of criteria (features), which included the percentage:

- $X_{1}$ - households equipped with a computer $\left(w_{1}=0.144\right)$,

- $X_{2}-$ households with the Internet access $\left(w_{2}=0.144\right)$,

- $X_{3}$ - people using a computer $\left(w_{3}=0.143\right)$,

- $X_{4}$ - people using the Internet $\left(w_{4}=0.143\right)$,

- $X_{5}$ - people using mobile devices to connect with the Internet $\left(w_{5}=0.071\right)$,

- $X_{6}$ - people using the Internet to communicate $\left(w_{6}=0.12\right)$

- $X_{7}$ - people using cloud services $\left(w_{7}=0.028\right)$,

- $X_{8}$ - people using the Internet in contacts with public administration $\left(w_{8}=0.054\right)$,

- $X_{9}$ - people using the Internet for goods or services for private use $\left(w_{9}=0.1\right)$,

- $X_{10}$-people using payments for goods and services purchased or ordered via the Internet for private use $\left(w_{10}=0.054\right)$.

The weight values for individual criteria are shown in brackets. The weight vector arose as a result of transforming the vector of mean variable values $\left[\bar{x}_{1}, \ldots, \bar{x}_{n}\right]$ into the scale vector $\left[\bar{w}_{1}, \ldots, \bar{w}_{n}\right]$, where the sum of elements equals one $(n=10)$. A rule was applied, according to which the degree of intensity of features characterizing ICT in the surveyed population corresponds to the priorities (weights) adopted for the assessment of Polish voivodeships. It was assumed that the most common features most strongly express the degree of digital exclusion. Possession or use of a computer or the Internet $\left(\bar{x}_{1}, \bar{x}_{2}, \bar{x}_{3}, \bar{x}_{4}\right)$ in Poland, in this period included approximately $81 \%$ of the surveyed persons or households (Fig. 1). These 


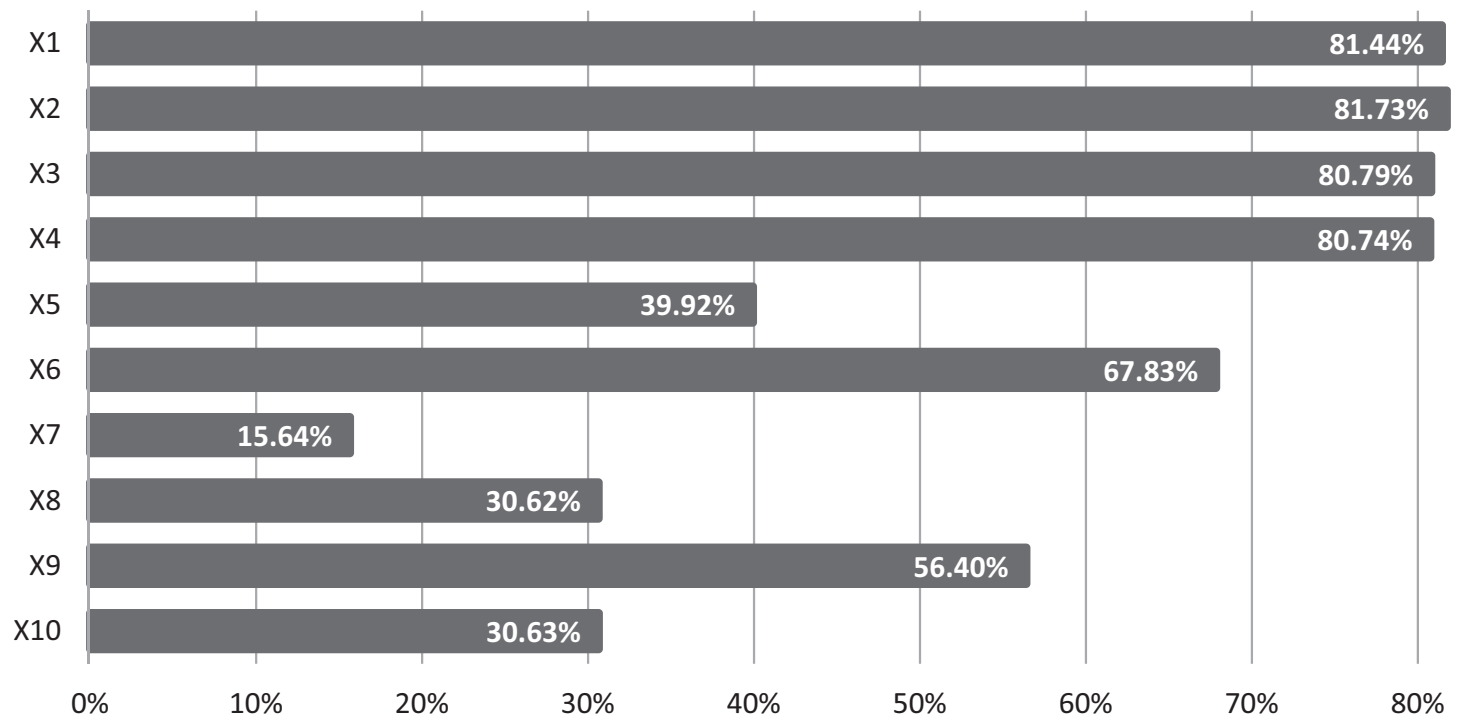

Figure 1. Average values of variables characterizing the percentage of people or households using ICT in Polish voivodeships in 2017

Source: own study based on CSO data (CSO, 2018).

criteria received the highest, over $14 \%$ preference level. However, the least popular feature (15.64\%), i.e. the use of cloud computing services, determined the digital exclusion to the lowest degree $(2.8 \%)$.

The ELECTRE TRI 2.0a computer program was used in the classification tests. The grouping into 3 classes was considered a result division. Due to the number of classes $k=3$, for the decision problem being considered, two profiles defining the class boundaries were defined: and for each $i$-th criterion $(i=1, \ldots, n)$, where $j$ denotes the index of the decision variant $(j=1, \ldots, m)$. Profile values divide the space between the minimum and maximum value of each criterion into three equal parts. For each of these profiles, threshold values have been determined on each criterion: vetoes, preferences and indistinguishability, $h=1, \ldots, k-1$. The proportions between the thresholds are proposed in the work of Rogers (2000) and Giannoulis and Ishizaka (2009). It was considered that the surpassing is reliable when the reliability ratio (Roy, 1991) exceeds the cut level $\lambda=0.76$.

The allocation of individual objects to classes was obtained as a result of two types of procedures: optimistic and pessimistic. The list of received assignments to groups is found in Table 1.
The numbering of the obtained groups was relate to the class's hierarchy of importance (variants from higher classes over the variants from lower classes were preferred). The regions classified as least at risk of digital exclusion were classified in the first group. The second one included average voivodeships. On the other hand, the third class represented the objects most exposed to finding themselves outside the digital community. Classes $1-2$ and 2-3 are undefined classes. They contain voivodeships that have been allocated to various classes as part of optimistic and pessimistic procedures. According to the applicable rule, in the ELECTRE TRI method, the allocations obtained by the optimistic procedure cover the higher classes compared to the results of the pessimistic procedure. For example, the Masovia Province according to the optimistic procedure was classified into the second group, while according to the pessimistic procedure, it found itself in the first class. This indicates the occurrence of some ambiguities, which result in the incomparability of the variant with the designated class profile. The final division is done by the decision-maker. In the article, it was proposed to introduce two uncertain classes for such cases. 
Proceedings of the 2018 International Scientific Conference 'Economic Sciences for Agribusiness and Rural Economy' No 2, Warsaw, 7-8 June 2018, pp. 306-312

Table 1. Results of the classification of voivodeships according to the degree of ICT use in households, in 2017

\begin{tabular}{|c|c|c|c|c|}
\hline Class 1 & Class 1-2 & Class 2 & Class 2-3 & Class 3 \\
\hline \multirow[t]{8}{*}{ Warsaw * } & $\begin{array}{c}\text { Masovia } \\
\text { (mazowieckie) }\end{array}$ & $\begin{array}{l}\text { Lower Silesia } \\
\text { (dolnośląskie) }\end{array}$ & $\begin{array}{l}\text { Kuyavia and Pome- } \\
\text { rania } \\
\text { (kujawsko-pomorskie) }\end{array}$ & $\begin{array}{c}\text { Lublin } \\
\text { (lubelskie) }\end{array}$ \\
\hline & $\begin{array}{c}\text { West Pomerania } \\
\text { (zachodnio-pomorskie) }\end{array}$ & $\begin{array}{l}\text { Masovia without } \\
\text { Warsaw * }\end{array}$ & $\begin{array}{c}\text { Łódź } \\
\text { (łódzkie) }\end{array}$ & $\begin{array}{l}\text { Lubusz } \\
\text { (lubuskie) }\end{array}$ \\
\hline & & $\begin{array}{c}\text { Opole } \\
\text { (opolskie) }\end{array}$ & $\begin{array}{l}\text { Lesser Poland } \\
\text { (małopolskie) }\end{array}$ & $\begin{array}{l}\text { Podlasie } \\
\text { (podlaskie) }\end{array}$ \\
\hline & & $\begin{array}{l}\text { Pomeranian } \\
\text { (pomorskie) }\end{array}$ & $\begin{array}{l}\text { Subcarpathian } \\
\text { (podkarpackie) }\end{array}$ & \\
\hline & & & $\begin{array}{l}\text { Silesian } \\
\text { (śląskie) }\end{array}$ & \\
\hline & & & $\begin{array}{c}\text { Holy Cross } \\
\text { (świętokrzyskie) }\end{array}$ & \\
\hline & & & $\begin{array}{l}\text { Warmia and Masuria } \\
\text { (warmińsko-mazurskie) }\end{array}$ & \\
\hline & & & $\begin{array}{l}\text { Greater Poland } \\
\text { (wielkopolskie) }\end{array}$ & \\
\hline
\end{tabular}

* Sub-regions of the Masovia Province.

Source: own study based on the CSO data (GUS, 2018).

Both in pessimistic and optimistic terms, there are objects that can be described as stable, that is definitely belonging to their groups, regardless of the procedure used. Among them are Warsaw (class 1), provinces: Lower Silesian, Masovia Province without Warsaw, Opole, Pomerania (class 2) and provinces: Lublin, Lubusz and Subcarpathian (class 3 ).

\section{CONCLUSIONS}

The research focused on the application of the ELECTRE TRI multi-criteria method of supporting the decision for grouping voivodeships due to the use of ICT in households in 2017. Based on the results, it can be concluded that there are significant disproportions in terms of individual advancement of ICT between Polish voivodeships. Regions with the highest digital exclusion of households (the lowest use of ICT) included the following voivodeships: Podlasie, Lublin and Lubusz. These regions belong to the group of voivodeships with lower economic indicators and GDP below the national average. Among the entities least threatened with the occurrence of this phenomenon were: Warsaw, Masovia and West Pomerania. It should be added that the sub-regions of the Masovia Province, Warsaw and Masovia Province without Warsaw were taken into account deliberately in the research. They show the disproportion of digital exclusion between residents of a large agglomeration and the rest of the region.

Factors that significantly affect the size of digital exclusion are, among others: income, education, qualifications and professional skills, place of residence and age. In order to reduce the regional disparities in digital access, one should strive to raise social capital, activate the unemployed and pensioners, and promote the use of ICT in professional and private life.

Nowadays, information, access to it and skilful processing are the main driver of economic growth 
and technological advantage. Human capital supported by the latest ICT technologies plays an important role in this process. The implementation of these technologies requires appropriate education, infrastructure and legal solutions. In areas with mental and cultural barriers and low level of knowledge in the use of ICT, there is a threat of digital exclusion. In Poland, the advantage of urban centres over rural areas in the use of ICT is noticeable. It results from infrastructural conditions. Therefore, in highly urbanized areas, higher skills in using modern IT solutions are noticed.

The obtained results of classification tests are an introduction to further work on topics related to digital exclusion. An interesting idea of continuation would be the analysis of this phenomenon in other countries, for example the European Union. In addition, a comparison of experiences related to digital exclusion of Poland and regions of Eastern Europe would allow obtaining information on how to prevent this phenomenon.

\section{REFERENCES}

1. Becker, J., Becker, A., Budziński, R. (2017). Multimethodological and multi-criteria decision analysis of objects in the computerized decision support system. Journal of Operations Research and Decisions, 27 (3), pp. 21-33.

2. Corrente, S., Greco, S., Słowiński, R. (2016). Multiple Criteria Hierarchy Process for ELECTRE TRI methods. European Journal of Operational Research, 252, pp. 191-203.

3. Dias, L., Mousseau ,V. (2003). IRIS: A DSS for Multiple Criteria Sorting Problems. Journal of Multi-Criteria Decision Analysis, 12, pp. 285-298.

4. Dijk, van J. (2010). Społeczne aspekty nowych mediów [Social aspects of new media]. PWN, Warszawa.

5. Doumpos M., Zopounidis C. (2002). Multi-criteria classification methods in financial and banking decision. International Transactions in Operational Research, 9, pp. 567-581.

6. Eurostat (2018). History of NUTS - Nomenclature of territorial units for statistics. Retrieved from: http:// ec.europa.eu/eurostat/web/nuts/history [Accessed 18.05.2018].

7. Figueira, J.R., Greco, S., Roy, B. (2009). ELECTRE methods with interaction between criteria: An exten- sion of the concordance index. European Journal of Operational Research, 199, pp. 478-495.

8. Figueira, J.R., Mousseau, V., Roy, B. (2016). ELECTRE Methods. In: Greco, S., Ehrgott, M., Figueira, J.R. (eds.) Multiple Criteria Decision Analysis. State of the Art Surveys, International Series in Operations Research \& Management Science, 233, pp. 155-185.

9. Giannoulis, C., Ishizaka, A. (2010). A Web-based decision support system with ELECTRE III for a personalised ranking of British universities. Decision Support Systems, 48, pp. 488-497.

10. Govindan, K., Jepsen, M.B. (2016). ELECTRE: A comprehensive literature review on methodologies and applications. European Journal of Operational Research, 250, pp. 1-29.

11. GUS (2018). The thematic area: Science and technology, Information society. Dział Wydawnistw Statystycznych GUS, Warszawa. Retrieved from: https://stat. gov.pl/obszary-tematyczne/nauka-i-technika-spoleczenstwo-informacyjne/spoleczenstwo-informacyjne/ [Accessed 18.05.2018].

12. International Telecommunication Union (2017). Measuring the Information Society Report. Retrieved from: http://www.itu.int/net4/ITU-D/idi/2017/\#idi2017ranktab [Accessed 08.05.2018].

13. La Gauffre, P., Haidar, H., Poinard, D., Laffréchine, K., Baur, R., Schiatti, M. (2007). A multicriteria decision support methodology for annual rehabilitation programs for water networks. Computer-Aided Civil and Infrastructure Engineering, 22, pp. 478-488.

14. Lu, G., Wang, H., Mao, X. (2010). Using ELECTRE TRI outranking method to evaluate trustworthy software, ATC' 10 Proceedings of the 7th international conference on Autonomic and trusted computing, Xi'an, China. Springer, pp. 219-227.

15. Merad, M.M., Verdel, T., Roy, B., Kouniali, S. (2004). Use of multi-criteria decision-aids for risk zoning and management of large area subjected to mining-induced hazards. Tunnelling and Underground Space Technology, 19, pp. 125-138.

16. Ministry of Investment and Development (2018). The website of the Digital Poland Operational Program. Retrieved from: https://www.polskacyfrowa.gov.pl [Accessed 18.05.2018].

17. OECD (2018). Directorate for Science, Technology and Innovation. Key ICT Indicators. Retrieved from: http:// www.oecd.org/sti/broadband/oecdkeyictindicators.htm [Accessed 08.05.2018].

18. Rogers, M. (2000). Using ELECTRE III to aid the choice of housing construction process within struc- 
Proceedings of the 2018 International Scientific Conference 'Economic Sciences for Agribusiness and Rural Economy' No 2, Warsaw, 7-8 June 2018, pp. 306-312

tural engineering. Construction Management and Economics, 18 (3), pp. 333-342.

19. Roy, B. (1991). The outranking approach and the foundations of ELECTRE methods. Theory and Decision, 31 (1), pp. 49-73.

20. Roy, B., Słowiński, R. (2008). Handing effects of reinforced preference and counter-veto in credibility of outranking. European Journal of Operational Research, 188, pp. 185-190.

21. Sanchez-Lozano, J.M., García-Cascales, M.S., Lamata, M.T. (2016). Comparative TOPSIS-ELECTRE TRI methods for optimal sites for photovoltaic solar farms. Case study in Spain. Journal of Cleaner Production, 127, pp. 387-398. 